\author{
Jerzy Sierociuk \\ Adam Mickiewicz University in Poznań \\ Institute of Polish Philology \\ ORCID: 0000-0001-9069-6117; e-mail: jasier@amu.edu.pl
}

\title{
About synonymy in dialects in the context of the general Polish language
}

\begin{abstract}
This article presents the issue of synonymy in dialects. The phenomenon is viewed in a context of contemporary dialectal lexicographic descriptions and the abounding material excerpted from a corpus of a dialect spoken in a single village in Wielkopolska (Bukówiec Górny, Leszno county). If we agree that synonymy is a stylistic phenomenon, choic e gains in importance as the prerequisite for a synonymic relation. The presented analyses indicate that a proper synonymic relation in dialects occurs only on the level of idiolects.
\end{abstract}

Keywords: dialect, idiolectal nature of vocabulary in dialects, vocabulary in dialects, synonymy in dialects.

\begin{abstract}
Abstrakt: W sprawie synonimii w gwarach - na tle polszczyzny ogólnej. W artykule podejmowany jest problem funkcjonowania $\mathrm{w}$ gwarach synonimii. Zjawisko to rozpatrywane jest zarówno w kontekście współczesnych dialektalnych opisów leksykograficznych, jak i bogatego materiału wyekscerpowanego z korpusu gwary jednej wsi wielkopolskiej (Bukówiec Górny, pow. Leszno). Uznając synonimię za zjawisko stylistyczne, przyjmuje istotne znaczenie w y b o r u jako podstawowego warunku zaistnienie relacji synonimicznej. Przedstawione wyniki analiz wykazują, że o właściwej relacji synonimicznej w gwarach można mówić jedynie na poziomie idiolektalnym.
\end{abstract}

Słowa kluczowe: gwara, idiolektalność leksyki gwar, leksyka gwar, synonimia w gwarach.

In an attempt at describing the alternative function of specific units in dialects, be it lexical or grammatical, first we need to tackle several theoretical issues. In this case, a definition must be coined of a dialect as well as a synonym (or variant). For clarity reasons I assume that a dialect is an oral phenomenon, operating with reference to oral traditions and messages. A synonym provides the possibility of choice.

Dialects follow developmental rules other than the general language; dialects do not undergo internalization - with reference to the general language, these functions fulfil all the sorts of grammar or, as Zuzanna Topilińska noted: "a prescriptive norm enforced by the local authorities' language policy (typically the government) and administratively executed" (Topolińska 1992: 251). It seems that it is of major importance to a description of how a dialect operates. 
On the other hand, we should take into account reservations of experts in stylistics, for example:

It seems impossible to define a lexical synonym without a prior analysis of the notion of choice which, this way or other, always accompanies a discussion of synonyms. After all, you choose from synonymous rhetorical forms (Skubalanka 1995, 43).

This quotation is a clear indication of $\mathrm{choice}$ as an element defining a synonym. I will refer to the possibility of choice very frequently. This is because we need to decide whether pairs of linguistic units, commonly presented to exemplify a synonymous relation, in fact offer the speaker the choice which stems from the definition.

Since choice is a commonly adopted element defining sy no n m s, in my presentation I will focus exclusively on this aspect. I have assumed that the decision if, in the course of oral communication, a specific language unit is indeed an element of a semantically equivalent pair, determines the subsequent research procedure.

These issues, of importance also to the general theory of synonyms, will be viewed by reference to dialects and the oral Polish language.

However, before I proceed with an analysis of specific conditions, let me focus on the relevant possibilities offered by the general Polish language in dictionaries of the Polish language and by analogical dialectal material presented in dictionaries of dialects. There is an important methodological difference between research into the general Polish language and the language spoken in rural areas. While many methodological solutions in research into the general and dialectal Polish language are common, they differ in the approach to two important conditions: time and space. The former does occur in research into the general Polish language but, basically, it defines the opposition between synchrony and diachrony. In fact, what is missing is the generational differentiation, more and more frequently considered in dialectological research. The other factor, space, differentiates the two research disciplines in a more decisive way. Dialectological methods have the ultimate goal of showing linguistic diversity in the geographic aspect, on language maps. Interestingly, the cartographic method of presenting data more and more often takes into account the differences affected by time i.e. the generational differentiation (Dejna 1998).

From a dialectologist's point of view, the general Polish language represents the condition of a dialect from a single research location in a strictly defined, narrow time frame. While dialectology takes into consideration the differences in the linguistic systems of the users of a specific dialect, using in research into the general Polish language material collected in the available general dictionaries is reminiscent of a dialectologist's daily contacts with a specific, single informant who is a dialect user. Another important difference, which allows to take a slightly different stance on the title issues, is the fact that dialectological research allows to verify the observations directly in the course of the research. There is an opportunity to gain insight into the linguistic structure of the dialect spoken by its users. In this situation, the following dependence emerges: the relations between the language variety in question and its specific implementation by specific users in a description of the general Polish language assumes that the language spoken by every person reflects lexicons. In 
a dialectological approach, it is the opposite: a general picture of the linguistic structure dialect results from individual idiolectal systems. Therefore, in the two cases, synthesis is approached from opposite directions.

Before I proceed with an analysis of specific examples which illustrate the issues under scrutiny, let me regard the relations between the basic notions at play, namely synonymy and variability. Without providing too many details about other authors' ideas, let me refer to the most popular approach presented in the Encyklopedia języka polskiego (Encyklopedia 1992). It says:

Synonymy is based on expressing the same content by means of two (several) different linguistic forms. Synonymy may pertain to syntax structures (rzucić kamieniem - rzucić kamień), morphological forms (inżynierowie - inżynierzy) and lexemes. Lexemes, which are related by synonymy, are referred to as synonyms. (Encyklopedia 1992, 343).

Variants - elements of a language treated identically with respect to their function even if their forms differ. Variants can be viewed as implementation of one and the same linguistic unit which some structuralist schools of thought tend to call invariants. Typically, variants are discussed in phonology (see Variants of a phoneme) (Encyklopedia 1992, 372).

If we assume that these definitions represent terms accepted by a majority of scholars we also need to assume that, as a relation largely based on semantic synonymity, synonymy can only be referred to the lexical level. On the other hand, variability is a functionally identical relation; therefore, defining it as equivalent to synonymy is not justified. If we also assume that, on the morphological level, allophony is marked by functional sameness accompanied by formal diversity (cf. above), attributing synonymity to units on the lexical (and higher) level is unjustified. When I allude to variability, I mean the relations taking place between phonological units and broadly-defined morphology: inflection and word formation.

The above suggests unambiguously that in the case of both synonymy and variability, there is a possibility of choice. However, in both situations the choice is made according to slightly different rules and between units of varying degrees of sameness.

After these theoretical considerations, let me proceed with reviewing selected examples that allow to take a stance on the major issues.

Dictionaries of the general Polish language provide numerous examples of lexical pairs of nearly identical meaning. The example below, which comes from the Stownik języka polskiego (M. Szymczak ed.), will be a starting point for the subsequent deliberations:

kolebka (...) a baby's crib equipped with a rocker or a different rocking device; a cradle

kolyska (...) a baby's crib equipped with a rocker or a different rocking device; a cradle (Szymczak 1979).

Based on both definitions, these two words should definitely be deemed synonyms. However, does it hold true for every situation? Let me refer to dialectological experience. 
Back in 1939, Józef Tarnacki wrote:

In Masovia, the two words (kolebka, kotyska) are in use although the older generation finds the word kotyska alien (Tarnacki 1939, 46).

The above statement clearly indicates that the synonymic relation between these two words in a specific use is not unambiguous at all. An analysis of how the words in question function in a dialectal environment leads to interesting conclusions. On top of the frequent lack of concurrent longevity of the verb form that can be a starting point for the derivative process (kolebać and kolysać, respectively), the informants use the words under scrutiny alternately. This happens frequently in the dialects spoken in the Lublin area, especially in the borderline area between Masovia and Lesser Poland. Therefore, in this situation, for a specific dialect user, the word kolebka does not necessarily need to be synonymous with kotyska because the informant knows only one element of the presented lexical pair.

Let me provide another example from the general Polish language which pertains to 'a (separated) place in a block of flats for storing prams'. Bearing in mind the word-forming rules of the general Polish language, you could expect a pair wózkownia : wózkarnia. This is because in contemporary Polish, names of rooms are created by adding suffixes -ownia and -arnia (and other) to the basis which here happens to be a noun (Grzegorczykowa, Puzynina 1979, 257 and 262). Respecting the above word-forming rules, these two words should be deemed synonyms. Meanwhile, the picture is quite surprising. In the eyes of regular users of the Polish language living in cities (the rooms are typical of blocks of flats), these forms are not synonymous because a majority of speakers know only one of them. While in Poznań and Gdynia, even in the local press, only the word wózkarnia is used, the inhabitants of Lublin also use only one word and it is wózkownia. To the inhabitants of the three cities, the words wózkarnia and wózkownia are not synonyms for a simple reason: being unaware of the other unit in the pair, they do not have a choice in the word forming or vocabulary.

Lately, there have been several works stimulating continued discussion of not only synonymy in dialects but also its specificity. The latest literature on the subject includes two special positions: Елена А. Нефедова, Многозначность и синонимия в диалектном пространстве (Нефедова 2008) and Gwary dziś. 5. Anna Kowalska, Apelatywne nazwy miejsc $w$ dialektach polskich. Derywacja sufiksalna (Kowalska 2011). Both works have been written with reference to vast material; in the Russian book, more emphasis is placed on the theoretical aspect of the issue, exemplified by representatives of four semantic fields ${ }^{1}$. The Polish monograph illustrates the phenomenon of my interest by providing more examples.

1 The "theoretical" chapter on "Многозначность и синонимия в пространстве диалекта" (pp. 21-84) is followed by a detailed analysis of the words from the semantic fields of 'TIME' (pp. 96-149), 'POGODA' (pp. 150-177), and morpho-semantic fields: 'LIFE' (pp. 178-293) and 'CAR TRAFFIC' (pp. 294-407). The monograph is based on north-Russian dialects spoken in the vicinity of Arkhangelsk; for years, the author has been member of a team publishing a dictionary of the dialects. 
A good context for these considerations has been provided by A. Kowalska who, among the names of 'places where various plants grow', refers to a series of 8 derivatives: jagodzisko // jagodowisko // jagodnik // jagodownik // jagodniak // jagodziniak // jagodniec // jagodziniec (Kowalska 2011, 125). However, this is not the longest series in the sub-chapter "Word-forming synonyms with a common basis and various suffixes"; the name of "premises for farm animals' boasts 9 derivatives: świniarnia // świniarka // świniarnik // świniatnik // świniusznik // świniarzec // świnioch // świniuch // świniak (Kowalska 2011, 125). This is not an exception, namely:

An even bigger number of synonyms defines 'a room where wood is stored' - some of them are derivatives with suffix extensions: -nia (drewutnia // drwalnia // drewnia // drewnialnia // drewarnia // drewkarnia // drewniarnia); -ka (drwalka // drzewiarka // drzewiarka // drewlarka // drewniarka // drewutka) and -nik (drewnik // drwalnik // drewiatnik); the remaining ones are drewutnisko // drewnica // drewiarek (Kowalska 2011, 125).

There are as many as 19 lexical units. This situation raises questions. Firstly, does an average speaker of a local dialect consider these forms synonymous? Do inhabitants of various regions in Poland know these words equally well? In this situation, do we deal with synonymy of dialectal forms of the type: koniewi : konioju : koniu (: koniowi)? For example, an inhabitant of Wielkopolska (to whom the form koniewi seems natural) will not be aware of the type konioju which exists in other (Masovian) dialects and vice versa. These forms will not offer a choice to individuals who live in the areas of the two dialects.

This global, general-dialectal approach to the research material leads to surprising conclusions.

All (...) dialects enjoy myriads (emphasis by J.S./ of grammatical forms and words, coupled with practically unlimited possibilities (emphasis by J.S.) of their alternations. However, the biggest variability, conditioned primarily by geography and the generations, is typical of vocabulary and dialectal inflection (Pelcowa 1996, 157).

With this statement in mind, I could conclude that dialects provide examples of high synonymity of the vocabulary system and equally high variability on the morphological level. The question about the point of reference in drawing these conclusions remains topical. By the way, in this situation, a question about the communication of speakers of dialects seems only natural. Are dialects orderly or perhaps they reflect "a linguistic mess", idiolectal freedom?

The answers to these questions are partly provided by an analysis of the material obtained from dialects with the biggest degree of variability both with respect to inflection and vocabulary (Pelcowa 1995, 156-57), namely the dialects spoken in the Lublin area. Their considerable diversity is partly attributed to the location in the borderland between Poland and Russia on one side and the borderland between Lesser Poland and Masovia. The reason why these dialects were chosen for observation was the fact that lexical research carried out by Halina Pelcowa in this area were supplemented by my research into dialectal word formation (Sierociuk 1996). Therefore, 
I am familiar with the lexical and word-forming diversity of these dialects. Another argument in favour of choosing this area for observation, is publication of maps; the material for them was obtained independently and with different research assumptions - cf. Pelcowa 1995, map 3. (A place in a barn where cereals are threshed (and Sierociuk 1996, map 8) 'A place in a barn where a cart can drive').

Let me take a look at the answers obtained in the field: H. Pelcowa recorded four lexemes: klepisko, boisko, bojowisko, tok; on a word formation map, these names are accompanied by sporadic sklepisko, scepisko and pobojowisko occurrences. One can assume that in the dialects of the Lublin area, there are at least seven words denoting a specific referent (with varying geographic longevity/. Can they all be deemed synonymous?

The seven confirmed lexemes can be deemed synonymous only in two cases:

1. If the e n t ire dialectal material is treated as counterbalance to confirmations of the general Polish language i.e. in accordance with a holistic approach to the opposition between a dialect and the general Polish language;

2. If we view these examples in a general dialectal context; here we would in fact decide against the geographic differentiation of dialects.

The mentioned maps do not reflect the existence of all the seven (or even four for that matter) names in a single village. While two (less frequently three) of the lexemes were recorded in several locations, I need to note that this is not common practice and their location does not seem to be incidental. Most frequently, these synonymous confirmations appear in areas where two competing lexical (morphological) units clash. A comparison of the word formation map placed in (Sierociuk 1996) and map (no. 2) from the same book, which shows the informant's year of birth, leads to a conclusion that a large majority of the alternative recordings appear where the material was obtained from (at least) two individuals. This allows to define another level of reference when synonymous features in dialects are identified: the synonymy of a dialect spoken in a single village.

The presented "synonymous" sequences are rarely included in monographs of dialects from a small area, especially within a single dialect. These sequences are frequently recorded by authors of dialectal dictionaries (i.e. focusing on a complex of dialects) - there are many examples to show. However, synonymy is an important problem in lexicographic works; some of the related issues were described by B. Wyderka (Wyderka 2006).

Therefore, it seems interesting to answer the question about the complexity of the phenomenon at hand in a context of the field material. A point in case is material obtained from inhabitants of a single village: Bukówiec Górny (near Leszno) in south-western Wielkopolska. We have regularly spoken to the inhabitants of the village for over 20 years. This research is supposed to result in a dictionary of the local dialect. The field exploration is focused on obtaining data that allow to view the complexity of the language system of a local dialect as well as material for a future dictionary of the language spoken in Wielkopolska. The goal is to obtain possibly most complete lexical material. Since the village has been subjected to special research considering various sociolinguistic aspects, the conversations have been held with a large group of respondents representing different generations (Sierociuk 2003). 
What are synonymous relations in a specific dialect like? Let me use the example of the words for 'a man who mows'. Because of the specificity of Wielkopolska dialects, for clarity reasons I need to add that I mean here 'a man who slashes" because in that area, for mowing cereals (or grass) the word sieczenie [slashing] is used (rather than koszenie [mowing] as is the case in a majority of dialects and the general language). In Bukówiec Górny, I recorded five words: kośnik, kosiarz, kosarz, kosynier and kosiarek. Certainly, this sequence should be included in the planned dictionary. However, are all these words synonymous? The answer is yes if we consider the dialect spoken in Bukówiec Górny as a whole. What are the relations like on the level of a specific user of a specific dialect?

Let me explain the method of obtaining the relevant material. In the course of the research, with all the conversations recorded, we strive to turn the exploration into a casual conversation on a specific subject. Each recorded session is dedicated to obtaining vocabulary from a selected thematic area which encourages the interlocutors to focus on a specific subject. Consequently, there is a possibility of registering very diverse vocabulary. At the basis of each conversation is a special (thematic) questionnaire which is a sort of a script filled with the content of each conversation. This procedure does not embarrass the informants, at the same time creating opportunities for discovering vocabulary (or grammatical forms) typically not included in a traditional questionnaire. The interlocutor has more freedom in expressing his or her thoughts, hence vocabulary from "related" thematic areas pops up in various circumstances. All the uses are natural, stemming from the natural course of the conversation.

The confirmations presented below were obtained in natural circumstances; they were not triggered off by a special question in the questionnaire. The confirmations appeared frequently in conversations on other subjects. Therefore, their presence in an utterance of a specific respondent reflects his/her natural language preferences, in this case - lexical.

The viewed material comes from 59 conversations with 46 individuals; the texts offer 600,000 word forms. Each of the presented uses is accompanied by the interlocutor's initials and his/her date of birth. This information provides general insight into the dynamics of the changes taking place in the local dialect. In this case, there are also changes to the possible linguistic preferences of the interlocutors.

A map from an atlas of the language and folk culture in Wielkopolska (AJKLW 1982) can serve as an introduction to this part of the analysis:

Bukówiec Górny was a research location (74.) for the AJKLW where map 331 shows the ranges of the name of interest. Two types were recorded: kośnik and kosynier. Our research, carried out 40 years after the atlas exploration (Sobierajski 1972), confirmed the longevity of five forms (as specified above). In the absence of longevity of the form which is at the base of the derivation process (verb kosić), kosiarz and kosarz should be treated like separate units; kosiarz may be treated as a transfer from another dialect (in similar situations, H. Górnowicz (Górnowicz 1967, 15) assumed that "this is a derivative imported from another dialect"), while kosarz could have emerged locally as a substantival derivative $(<k o s a)$.

Below, I present the frequency of the specific forms in utterances of 21 individuals. In fact, a synonymous relation takes place only with reference to the pair kośnik // 


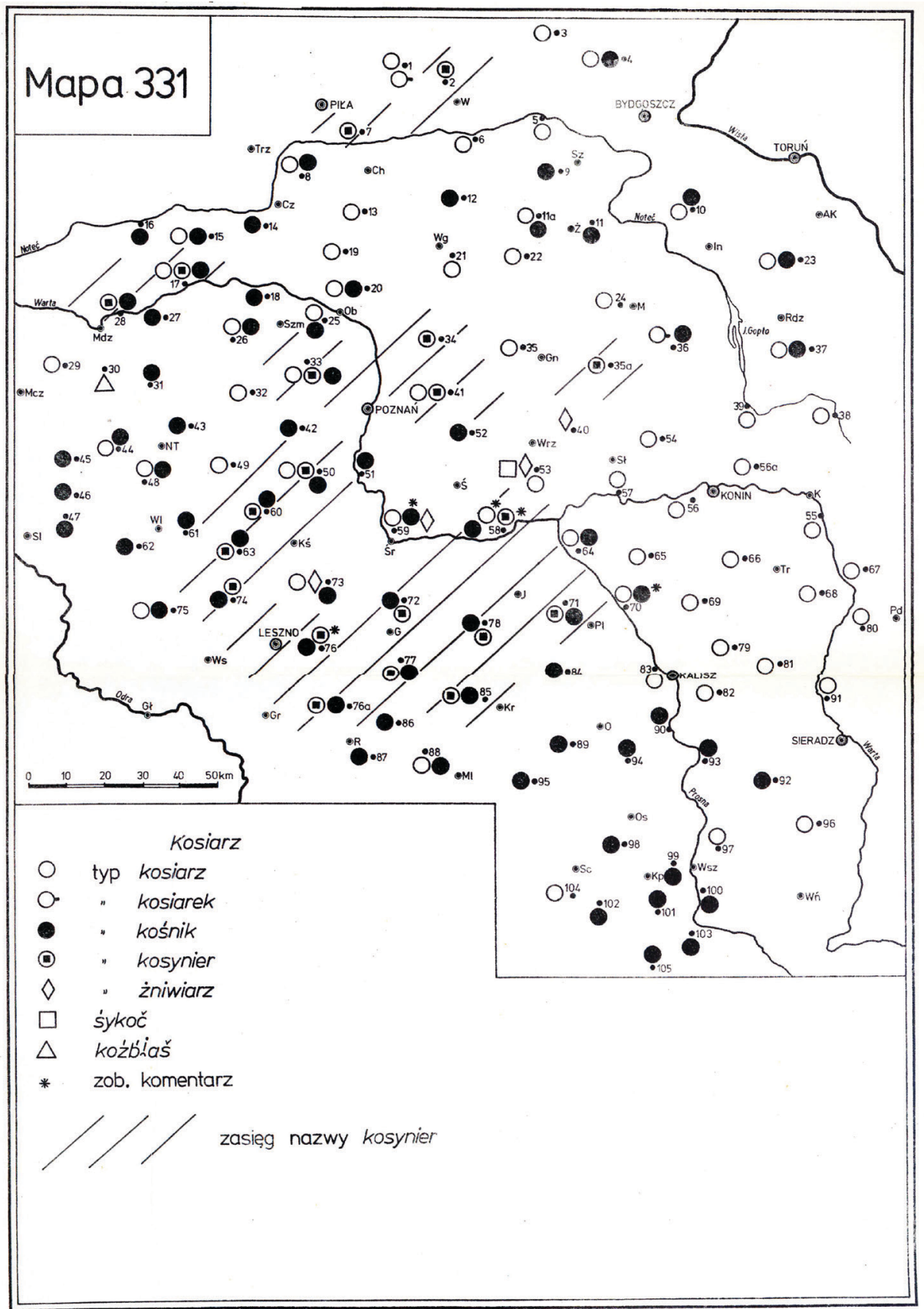

Zakład Narodowy im. Oseolinekich - Wydawnictwo

Wroctaweka Drukarnia Naukowa

Map 331. Kosiarz. Type kosiarz

See comment. Range of word kosynier 
kosiarz; the first form in the considered material appeared 104 times; the other form 23 times. This result should be topped with 3 confirmations of the phonetic variant (kosiorz) which appeared once in each utterance of various interlocutors.

$\begin{array}{lcc} & \text { kośnik } & \text { kosiarz } \\ \text { SoW (1920) } & 10 & 2 \\ \text { DoS (1921) } & 0 & 1 \\ \text { SlJ (1923) } & 3 & 5 \\ \text { SzJ (1925) } & 9 & 4 \\ \text { SoF (1928) } & 6 & 2 \\ \text { SoA (1928) } & 5 & 3 \\ \text { MlP (1929 } & 5 & 4 \\ \text { MaM (1948) } & 5 & 1 \\ \text { WoM (1968) } & 0 & 1 \\ & & \\ \text { TaF (1914) } & 2 & \\ \text { UrA (1912) } & 3 & \\ \text { SoW (1920) } & 10 & \\ \text { SzA (1923) } & 12 & \\ \text { KaM (1923) } & 3 & \\ \text { SoF (1928) } & 6 & \\ \text { PoW (1928) } & 3 & \\ \text { MaE (1929) } & 3 & \\ \text { MlP (1929) } & 5 & \\ \text { LiE (1935) } & 3 & \\ \text { BaK (1947) } & 7 & \\ \text { MaH (1955) } & 4 & \end{array}$

The variant kosior, a phonetic variant, was uttered by 3 individuals:

SlJ (1923) 1

PoB (1937) 1

DrZ (1962) 1

The remaining forms were confirmed as follows:

$$
\begin{array}{lll}
\text { kosarz } & -1 & (\text { SbW }-1917) \\
\text { kosiarek } & -3 & (\text { PoW [1928] - 2), (DrZ [1962] - 1) } \\
\text { kosynier } & -2 & (\text { GuB - 1946) }
\end{array}
$$

On top of synonymy, the above set is also a mark of a methodological problem of importance to atlas research. This is related to the selection of the informant who may have specific idiolectal preferences. In many cases, the managers of atlas projects limit the exploration to a single respondent; examples of this solution are included in the 
Atlas gwar polskich by Karol Dejna² (Dejna 1998). The "List of points, informants and explorers" included there (Dejna 1998, 37) contains this type of information:

709 Wilkowyja, Garwolin county, Siedlce province (Garwolin county). Informant: Franciszek Sarek, born in 1880. Explorer 1956 Karol Dejna.

709W - Wilkowyja, Garwolin county. Informant Katarzyna Borkowska, born in 1913. Explorer 1992 Stanisław Jankowski.

713 Grabów, Grabów n. Pilicą county, Radom province (Kozienice county). Informant Józef Rosiński, born in 1885. Explorer 1957 Karol Dejna.

713G - Grabów, Grabów n. Pilicą county. Informant Franciszek Kuchciński, born in 1931. Explorer 1989 Stanisław Jankowski.

Therefore, in a discussion of synonymy in a dialectal environment, attention should be drawn to the specificity of the phenomenon. In a local dimension (a dialect of a single village), synonymy seems to be a phenomenon with relatively limited longevity. The presented material suggests that in an idiolectal system (especially that of the older generation), verbal homogeneity is preferred. Therefore, extended synonymy is not confirmed in the light of field explorations. In this situation, dialectal dictionaries cannot be used to survey dialectal synonymy, especially when they cover large areas. In many cases, what is a synonym for a lexicographer, is a foreign element to a dialect user. From the point of view of lexicographic practice, it would be more appropriate to refer to tautonymous relations.

Therefore, viewing the possible emergence of synonyms in dialects should not exceed the idiolectal level, the language spoken by a specific individual. In fact, it is only on this level where possible synonymy or semantic synonymous features of words can be discussed. However, direct contacts with informants in the field sometimes result in confirmations which cannot be interpreted in an unambiguous way. To be more precise, these are situations when asked a question /especially/ from the questionnaire about a name/, an informant says: $\mathbf{X}$... but some also say $\mathbf{Y}$; or: $\mathbf{X}$... but others say $\mathbf{Y}$ or $\mathbf{Z}$. Are these confirmations evidence of synonymy? Are the forms from the replies synonymous from the point of view of the informant's language? Partly, this is reminiscent of a situation when someone starts to learn different words in a foreign language. From the point of view of an individual's language system, these are not exchangeable units in communication.

The above presented material triggers off more general questions; in the case of dialectological considerations (and specific examples in dialectal research), of importance is the point of reference when an alternative form is indicated, creating a pair based on synonymic relations: synonymous with what..., and in what conditions?

In reference to the material considered here, the above question becomes relevant when we realise that the Polish language in its oral version is an area where the law

\footnotetext{
${ }^{2}$ Interestingly, the atlas questionnaire contains 2,000 questions.
} 
of linguistic economy prevails. Agreeing to that, we significantly weaken the statement about the exceptional richness of lexical synonymy (and variability) in dialects*.

\section{Bibliography}

AJKLW 1982: - Atlas języka i kultury ludowej Wielkopolski, vol. III. Rolnictwo, eds. Z. Sobierajskiego i J. Burszty, Wrocław-Warszawa-Kraków-Gdańsk-Lódź.

Dejna K. (1998), Atlas gwar polskich. Volume 1. Matopolska, Warszawa.

Encyklopedia (1992), Encyklopedia języka polskiego, Wrocław.

Grzegorczykowa R., Puzynina J. (1979), Stowotwórstwo wspótczesnego języka polskiego, Warszawa.

Górnowicz H. (1967), Formanty przyrostkowe w gwarach malborskich (part I), "Rozprawy Komisji Językowej ŁTN", Łódź, pp. 13-53.

Kowalska A. (2011), Gwary Dziś 5: A. Kowalska, Apelatywne nazwy miejsc w dialektach polskich. Derywacja sufiksalna, Poznań.

Нефедова Е. А. [Nefedova] (2008), Многозначность и синонимия в диалектном пространстве [Mnogoznachnost i cinonimija v dialektnom prostranstve], Москва.

Pelcowa H. (1995), Wariantywność leksykalna gwar pogranicza wschodniego Lubelszczyzny, [w:] Badania dialektów i onomastyki na pograniczu polsko-wschodniostowiańskim, M. Kondratiuk (ed.), Białystok, pp. 155-166.

Pelcowa H. (1996), Wariantywność a interdialektalność zjawisk gwarowych, [in:] Prace Naukowe UŚ w Katowicach nr 1577, Prace Językoznawcze 24. Studia historycznojęzykowe, A. Grybosiowa and A. Kowalska (ed.), Katowice, pp. 156-169.

Sierociuk J. (1996), Budowa wybranych formacji rzeczownikowych - szczególnie nazw miejsc w gwarach między Wisła a Wieprzem, Lublin.

Sierociuk J. (2001), W sprawie synonymy w polszczyźnie ogólnej $i$ w gwarach, [in:] Leksyka a gramatyka w tekście językowym, K. Wojtczuk (ed.), Siedlce, pp. 195-203,

Sierociuk J. (2003), Założenia metodologiczne badań języka wsi, "Poznańskie Spotkania Językoznawcze”, vol. XI, Z. Krążyńska and Z. Zagórski (eds.), Poznań, pp. 131-136.

Sierociuk J. (2012), Problem wariantywności i synonymy $w$ dociekaniach dialektologicznych [in:] Čeština v pohledu synchronním a diachronním. Stoleté kořeny Ústavu pro jazyk český, Světla Čmejrková, Jana Hoffmannová, Jana Klímová (eds.), Universita Karlova v Praze, Praha, pp. 351-355.

Skubalanka T. (1995), Problemy synonymy poetyckiej, [in:] Skubalanka T., O stylu poetyckim $i$ innych stylach języka, Lublin, pp. 43-58.

Sobierajski Z. (1972), Kwestionariusz do Atlasu języka i kultury ludowej Wielkopolski, part I: Stownictwo - Fonetyka - Stowotwórstwo, questions 1-645 (cooperation by M. Gruchmano-

* This is an extended text of the issues as presented in: W sprawie synonimii w polszczyźnie ogólnej i w gwarach, [in:] Leksyka a gramatyka w tekście językowym, K. Wojtczuk (ed.), Siedlce, 195-203, and Problem wariantywności i synonimii $w$ dociekaniach dialektologicznych, [in:] Čeština v pohledu synchronním a diachronním. Stoleté kořeny Ústavu pro jazyk český, Světla Čmejrková, Jana Hoffmannová, Jana Klímová (eds.), Universita Karlova v Praze, Praha 2012, pp. 351-355. 
wa, H. Nowak, Z. Zagórski); part. II: Deklinacja - Koniugacja - Składnia, questions 6461380 (cooperation by M. Gruchmanowa, H. Nowak); part III: Etnographica, questions 1381-1953 (supplemented by T.Wróblewski); part IV: Ilustracje, Poznań.

Szymczak M. (ed.) (1979), Stownik języka polskiego, vol. I-III, Warszawa.

Tarnacki J. (1939), Studia porównawcze nad geografia wyrazów (Polesie - Mazowsze), Warszawa.

Topolińska Z. (1992), Miejsce dialektologii wśród innych dyscyplin slawistycznych. [in:] Z polskich studiów slawistycznych, seria 8, Wydawnictwo Energia, Warszawa, pp. 249-254.

Wyderka B. (2006), O synonymy w gwarach i problemach jej opisu, [in:] Gwary Dziś 3: Wewnętrzne zróżnicowanie języka wsi, J. Sierociuk (ed.), Poznań, pp. 127-134. 